\title{
A review of issues in seagrass seed dormancy and germination: implications for conservation and restoration
}

\author{
Robert J. Orth ${ }^{*, * *}$, Matthew C. Harwell, Eva M. Bailey, Aaron Bartholomew, \\ Jennifer T. Jawad, Alfonso V. Lombana, Kenneth A. Moore, Jennifer M. Rhode, \\ Helen E. Woods
}

Virginia Institute of Marine Science, School of Marine Science, College of William and Mary, Gloucester Point, Virginia 23062, USA

\begin{abstract}
Seagrasses have received considerable attention over the past 2 decades because of the multiple ecological roles they play in estuarine and coastal ecosystems and concerns over worldwide losses of seagrass habitat due to direct and indirect human impacts. Restoration and conservation efforts are underway in some areas of the world, but progress may be limited by the paucity of information on the role of seeds in bed dynamics. Although flowering occurs in most of the 58 seagrass species, seed germination data exist for only 19 of the 42 species that have some period of dormancy, with only 93 published references to field and/or laboratory studies. This review addresses critical issues in conservation and restoration of seagrasses involving seed dormancy (e.g. environmental vs physiological), existence and type of seed bank (transient or persistent), and factors influencing seed germination (e.g. salinity, temperature, light). Results of many earlier published studies relating seed germination to various environmental factors may need re-examination given more recent published data which show a confounding influence of oxygen level on the germination process. We highlight the importance of conducting ecologically meaningful germination studies, including germination experiments conducted in sediments. We also identify questions for future research that may figure prominently in landscape level questions regarding protected marine or estuarine reserves, habitat fragmentation, and restoration.
\end{abstract}

KEY WORDS: Seagrasses · Seeds · Dormancy · Seed banks · Germination · Restoration · Conservation

\section{INTRODUCTION}

Seagrasses, marine angiosperms comprising 58 species in 11 genera, occur in all coastal waters of the world except the Antarctic (den Hartog 1970). They have been receiving increasing attention worldwide since the 1970 s because of recognition of (1) their mul-

\footnotetext{
•E-mail: jjorth@vims.edu

" The order of the 2 primary authors was assigned based on contribution to the manuscript. The remaining authors are arranged alphabetically
}

tiple ecological functions in estuarine and coastal systems, such as nursery and fish habitat (Coles et al. 1987, Heck et al. 1997) and regions of high primary and secondary production (Larkum et al. 1989, Edgar 1990, Fredette et al. 1990), and (2) losses in many areas of the world due to anthropogenic inputs of nutrients and sediments (Short \& Burdick 1996, Short \& WyllieEcheverria 1996). In addition, considerable seagrass area has been permanently lost to coastal development, primarily from dredge and fill operations (Short et al. 1991) or altered due to commercial/recreational activities such as propeller and anchor scarring 
(Walker et al. 1989, Sargent et al. 1995, Dawes et al. 1997). These issues have led to recent developments in efforts to both restore and conserve these habitats (Fonseca et al. 1998).

Although seagrass restoration has focused on mature or adult plants, discussions over the last decade on biodiversity issues (National Research Council 1995) that entail both conservation biology and restoration ecology suggest that seed ecology should be a critical research topic. Seagrass reproduction and seed output have been largely ignored in questions related to their potential contribution to population structure and genetics, plant demographics, bed maintenance, or in the development of new beds (Kirkman \& Kuo 1990, Orth et al. 1994, Williams \& Davis 1996, Piazzi et al. 1998, Marba \& Walker 1999, Orth 1999). We believe that for conservation and restoration of seagrasses to be effective, more research into their seed germination ecology must be conducted.

Most of the 58 reported species of seagrasses are known to flower and produce fruit, but differ dramatically in seed anatomy and germination strategy (den Hartog 1970). Kuo \& Kirkman (1996) characterized the seagrass genera into 3 classes based on seed anatomy, nutrient storage, and germination strategy (Table 1). Seeds from 2 of these classes do not exhibit any type of dormancy, with 1 class, which comprises 4 species in 2 genera, exhibiting viviparous development. The third class, comprising 42 species in 7 genera, produces
Table 2. Seed bank, dormancy, and germination citation counts from the published seagrass literature (from 1938 to 2000)

\begin{tabular}{|lc|}
\hline Genus & Number of citations \\
\hline Zostera spp. & 58 \\
Halophila spp. & 13 \\
Cymodocea spp. & 8 \\
Halodule spp. & 6 \\
Phyllospadix spp. & 4 \\
Syringodium sp. & 4 \\
\hline
\end{tabular}

seeds with a hard seed coat and some period of dormancy.

Despite more than a century of scientific research and over $2000 \mathrm{yr}$ of recorded observations on factors influencing the dormancy and germination of seeds in terrestrial systems (Baskin \& Baskin 1998), there is a dearth of information on seagrass seeds. Searches of the published literature (from 1938 to 2000) revealed seed-based information on only 19 of the 42 seagrass species (Table 2). These studies found some level of seed dormancy, with 93 references to field observations or laboratory/field experiments on seed germination (Appendix 1). This review, which concentrates on the group of 42 species that have some period of dormancy (Kuo \& Kirkman 1996), addresses critical issues in conservation and restoration of seagrasses involving seed dormancy, existence and type of seed banks, and

Table 1. Comparison of the type of fruit and seed covering, dormancy, and seed bank characteristics for the 12 genera of seagrasses (modified from Kuo \& Kirkman 1996). Definition of dormancy after Fenner (1995), but modified to include seeds that appear to have a highly variable dormancy period. Viviparous = viviparous reproduction

\begin{tabular}{|c|c|c|c|c|c|}
\hline Genus & Fruit/seed covering & Dormancy & Seed bank & Length of dormancy & Source \\
\hline \multicolumn{6}{|l|}{ Class 1} \\
\hline Posidonia & Membranous & Not distinct & None & None & Kuo \& Kirkman (1996) \\
\hline Thalassia & Membranous & Not distinct & None & None & Kuo \& Kirkman (1996) \\
\hline \multicolumn{6}{|l|}{ Class 2} \\
\hline Amphibolis & Viviparous & Not distinct & None & None & Kuo \& Kirkman (1996) \\
\hline Thalassodendron & Viviparous & Not distinct & None & None & Kuo \& Kirkman (1996) \\
\hline \multicolumn{6}{|l|}{ Class 3} \\
\hline Cymodocea & Hard & Distinct & Transient & Up to $12 \mathrm{mo}$ & $\begin{array}{l}\text { Reyes et al. (1995), Pírc et al. } \\
\text { (1986) }\end{array}$ \\
\hline Halodule & Hard & Distinct & Persistent & $46 \mathrm{mo}$ & McMillan (1991) \\
\hline Halophila & Hard & Distinct & Persistent & $\mathrm{Up}$ to $24 \mathrm{mo}$ & McMillan \{1991\} \\
\hline Heterozostera & Hard & Distinct & Unknown & Unknown & Kuo \& Kirkman (1996) \\
\hline Phyllospadix & Hard & Distinct & Transient & $2 \mathrm{wk}-12 \mathrm{mo}$ & $\begin{array}{l}\text { Turner (1983), Kuo et al. (1990), } \\
\text { Reed et al. }(1998)\end{array}$ \\
\hline Syringodium & Hard & Distinct & Persistent & $49 \mathrm{mo}$ & McMillan (1991) \\
\hline Zostera & Hard & Distinct & Transient & $\mathrm{Up}_{\mathrm{p}}$ to $12 \mathrm{mo}$ & $\begin{array}{l}\text { Orth \& Moore (1983), Moore et } \\
\text { al. (1993) }\end{array}$ \\
\hline
\end{tabular}


factors influencing seed germination. This review does not include freshwater submersed macrophytes, such as Ruppia spp. (for review see Kantrud 1991), which are considered euryhaline and often found co-occurring with seagrasses.

\section{DORMANCY}

Species which have some form of dormancy are able to disperse through time as well as space by physical and/or biological vectors (Chambers \& MacMahon 1994, Fenner 1995). Terrestrial plants exhibit a suite of dormancy strategies, from willow Salix spp., whose seeds germinate in days to weeks, to moth mullein Verbascum blattaria, whose seeds can stay dormant for 1000 yr (Fenner 1995, Baskin \& Baskin 1998 and references within). As both spatial and temporal disturbances occur in seagrass communities, some form of seed dormancy in seagrasses can be important for long-term population persistence. Many definitions of dormancy have been introduced, based, in part, on the factors that control dormancy (Hilhorst \& Karssen 1992, Baskin \& Baskin 1998). Classification of dormancy can be assigned according to the residence time in the seed bank (Simpson 1990), the timing of dormancy initiation (Hilhorst \& Toorop 1997), or the mechanisms preventing germination (Baskin \& Baskin 1998). Classification of plant communities is often founded on the transient or persistent nature of seed banks. From the perspective of the mechanisms controlling dormancy and germination in a given species, the seed developmental stage at which dormancy is imposed is of importance. Dormancy initiated during seed development requires a physiological mechanism, such as embryo maturation, to initiate germination. Dormancy initiated at the time of seed release requires an environmentally mediated factor, such as temperature or oxygen stratification, to initiate germination.

Primary dormancy occurs when dormancy is imposed on the developing seed attached to the parent plant, while secondary dormancy is associated with dormancy regulation factors that occur in the seed bank (Hilhorst \& Toorop 1997). The seagrass literature suggests that dormancy is initiated during seed development; however, we are unaware of any studies which test if seeds of those species in the third class (Table 1) will germinate immediately after release from the parent plant.

While dormancy is not a life history strategy for several seagrass genera (notably Posidonia, Thalassia, and Amphibolis), dormancy has been demonstrated in others and ranges from a few weeks (Phyllospadix torreyi, Reed et al. 1998) to up to 4 yr (Syringodium filiforme, McMillan 1983a). A critical question that has

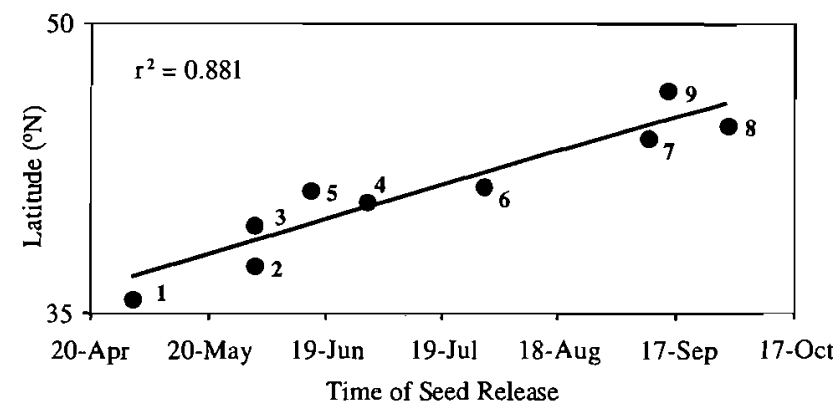

Fig. 1. Correlation between timing of seed release and latitude in 9 populations of Zostera marina along the east coast of North America. Notations (in order of increasing latitude) ${ }^{1}$ North Carolina, Phillips (1972); ${ }^{2}$ Virginia, Moore et al. (1993); ${ }^{3}$ New Jersey, Phillips (1972); ${ }^{4} \mathrm{New}$ York, Phillips (1972); ${ }^{5}$ Rhode Island, Churchill (1983); ${ }^{6}$ Massachusetts Addy (1947, Phillips (1972); ${ }^{7}$ Maine, Phillips (1972); ${ }^{8}$ Nova Scotia, Phillips (1972); ${ }^{9}$ New Brunswick, Keddy \& Patriquin (1978)

not been addressed in these studies is whether the environment or some physiological characteristic of the seed is responsible for preventing germination (i.e. environmental vs organic [physiological dormancy], Baskin \& Baskin 1998). As in studies on other plant physiology systems, there can be a high degree of interaction between factors (Thomas 1992, Ungar 1995, Hilhorst \& Toorop 1997, Khan \& Ungar 1997).

Harrison (1991) used seeds collected from parent plants and from the seed bank ( 1 mo after seed release) to examine dormancy in Zostera marina. His experiments, conducted under various temperature and salinity conditions with scarified (i.e. scored) seed coats, concluded that both physiological and physical dormancy exist in this species. Published data (Addy 1947, Phillips 1972, Keddy \& Patriquin 1978, Churchill 1983, Moore et al. 1993) from this species' latitudinal range along the North American coast from North Carolina to Canada shows a progressively later period of seed release with increasing latitude (Fig. 1). However, evidence from 3 locations (Virginia, New York, Massachusetts; Fig. 1) suggests that germination occurs in the fall regardless of latitude, suggesting that dormancy may be under environmental rather than inherent physiological control (Baskin \& Baskin 1998). Other observational studies have addressed issues of timing of flowering (Jacobs \& Pierson 1981) and seed production (Phillips et al. 1983, Silberhorn et al. 1983), and seed release (Fig. 1) along latitudinal gradients; however, seed dormancy has not been tested along a latitudinal gradient under rigorous experimental conditions.

The maintenance of dormancy in terrestrial seeds can be attributed to a variety of factors (Simpson 1990, Hilhorst \& Toorop 1997, and references within both), including hormones, secondary plant compounds (i.e. 
for allelopathy), light, temperature, salinity, gases $\left(\mathrm{CO}_{2}\right.$ and $\mathrm{O}_{2}$ ), and nutrients. For seagrasses, studies of these factors have examined their influence on seagrass seed germination rather than dormancy maintenance. Research on maintaining seagrass seed dormancy has been restricted mainly to studies of the retention of seeds for artificial seed reserves (e.g. McMillan 1991, Brenchley \& Probert 1998).

\section{SEED BANKS}

Seed banks have been studied extensively in many plant ecosystems (Skoglund 1992 and references within) with the notable exception of seagrass meadows. Seed banks are often classified by the type of dormancy present, and they can vary greatly in their characteristics. The seed bank for a given species is population-specific and can be either transient (turn over in less than $1 \mathrm{yr}$ ) or persistent (seeds that remain longer than 1 yr) (Simpson 1990). The length of time a seed remains in the seed bank can be critical as longterm population stability is influenced by whether or not the seed reserve exists through the next reproductive cycle (i.e. a 'true' seed bank).

Seed banks are characterized best by a number of generalities. First, distribution of seeds in a seed bank is extremely patchy (Fenner 1995) and temporal variability of seeds in the seed bank can exist in a plant community having either transient or persistent species. This variability makes analyzing seed banks difficult because they require high spatial and temporal sampling resolution (Fenner 1995 and references within). Second, the size of the seed is often directly related to its persistence in the seed bank. This property appears to be a function of per capita expenditure of energy, ability of the seed to percolate into the sediment, and potential to avoid predation (Fenner 1995). Third, abundance of seeds in a seed bank varies by plant community type.

Seed banks in seagrass communities have not been studied extensively. Estimates of seed bank size for seagrasses are comparable to those of most plant community types (Table 3) (Fenner 1995 and references within); however, Inglis (2000) found large heterogeneity in Halodule uninervis seed banks at multiple spatial scales. Harrison (1993) documented the dynamics of a Zostera marina seed bank in the Netherlands, showing high spatial and temporal variability in a single population. A significant portion of the seeds in the seed bank were lost to autonomous death and a small percentage of the seeds contributed to a persistent seed bank. McMillan (1991) reported seeds of the following seagrass species collected from various sources surviving more than 12 mo under laboratory conditions: Syringodium filiforme, $49 \mathrm{mo} ; H$. uninervis, $41 \mathrm{mo}$ Halophila engelmannii, $24 \mathrm{mo}_{;}$Halodule wrightii, up to 46 mo.

Several studies have described the conditions necessary to store seeds, an indirect approach for understanding natural seed banks. Conacher et al. (1994b) reported a maximum of a $50 \mathrm{~d}$ storage period for Zostera capricorni seeds under conditions of aeration and low temperatures $\left(5\right.$ to $\left.10^{\circ} \mathrm{C}\right)$. Churchill (1983) found high survival ( $8 \mathrm{mo}$ ) of $Z$. marina seeds stored in water at room temperature. Reed et al. (1998) found that storage of Phyllospadix torreyi seeds under cold, dark conditions could delay germination by up to $83 \mathrm{~d}$.

\section{SEED GERMINATION}

Successful seed germination following some period of dormancy results from an interaction between physiological and genetic factors (internal) and environmental factors (external), including sediment, light, and temperature (Baskin \& Baskin 1998). Both internal and external processes have the potential to create a seed bank for a given population. Critical environmental cues that influence germination can vary over short horizontal and vertical distances as characteristics of the physical environment (e.g. sediment type, $\mathrm{pH}$, organic matter) and biological environment (e.g. abundance and type of sediment-dwelling animals, physical arrangement of plant and animals in space and time) interact to create a mosaic of microclimates (Hamrick \& Lee 1987, Woodin et al. 1998).

Termination of dormancy or initiation of germination/seedling growth is influenced by hormones, light (photoperiod), temperature, water (e.g. imbibition, osmotic changes, salinity), nutrients, or mechanical cues (Hilhorst \& Karssen 1992, Gutterman 1994). Factors critical to this process can be seed-specific, so the intraspecific range for each factor may span several orders of magnitude (Hilhorst \& Toorop 1997). Thus, exact mechanisms are often considered nebulous as

Table 3. Size of seed bank for a variety of plant community types (Fenner 1995) compared to seagrasses

\begin{tabular}{|lc|}
\hline Plant community type & Seed bank size $\left(\mathrm{m}^{-2}\right)$ \\
\hline Arable communities & $20000-40000$ \\
Grasslands/moorlands & $5000-20000$ \\
Temperate forests & $1000-10000$ \\
Tropical forests & $100-1000$ \\
Salt marshes & $100-1000$ \\
Subarctic/alpine forests & $10-100$ \\
Seagrasses & $1-30000$ \\
& \\
aSee references in Appendix 1 for seed bank studies
\end{tabular}


the existence of multiple factors can preclude identifying the exact mechanism of dormancy termination/ germination initiation (Hilhorst \& Karssen 1992, Bewley 1997). Additionally there are often interactions between several factors (e.g. salinity and temperature on halophytes, Ungar 1995, Khan \& Ungar 1997).

Field and laboratory studies of seagrass germination have focused primarily on salinity, temperature, light, scarification, and, more recently, the sediment where seeds germinate (e.g. oxygen [oxygen-reduction profiles or $E_{h}$ ], Moore et al. 1993, Brenchley \& Probert 1998), as critical cues influencing germination processes (Appendix 1). However, no work has been conducted on the precise physiological mechanisms leading to seagrass seed germination. More importantly, it is critical that all seagrass seed germination studies identify a standard 'definition' of germination (e.g. Brenchley \& Probert 1998) for comparison to other work, including not just rupture of the seed coat but emergence and growth of the cotyledon (Churchill 1983, Brenchley \& Probert 1998).

Most published work on seed germination has been conducted under aerobic, non-sediment conditions, studying temperature and salinity and their interactions (Appendix 1). The majority of studies have demonstrated increased germination at reduced salinities (Zostera noltii, Hootsmans et al. 1987, Loques et al. 1990; Cymodocea nodosa, Caye \& Meinesz 1986). Other studies have shown no effect of salinity on germination (Syringodium filiforme, McMillan 1981; Halodule wrightii, McMillan 1981; Z, marina [perennial form]. Hootsmans et al. 1987; $Z$. marina [annual form], McMillan 1983b; $Z$. capricorni, Conacher et al. 1994b). Seeds of $Z$. capricorni (Conacher et al. 1994b) germinated at all tested temperatures $\left(15\right.$ to $\left.30^{\circ} \mathrm{C}\right)$ at low salinity $(1,5$, and $10 \%)$, while seeds held at higher salinities $(20,30$, and $40 \%)$ germinated only at lower temperatures. Several studies suggest that temperature stratification may be critical for germination of seeds, but it is not clear whether stratification is a necessary condition for seagrass seed germination, as in many terrestrial species (Baskin \& Baskin 1998), because of the potential confounding issues created by germinating seeds without sediment (e.g. different oxygen environment, Moore et al. 1993). Further, seagrass seed germination experiments conducted at low salinities (e.g. 1\% from Conacher et al. 1994b) may not reflect ambient field conditions.

Both photoperiod and specific wavelengths of light are important for germination in terrestrial systems (Thomas 1992, Gutterman 1994, Fenner 1995, Hilhorst \& Toorop 1997). McMillan (1987, 1988b) found light to be an important inducer of germination for both Halophila engelmanii and $H$. decipiens, while Birch (1981) reported germination of $H$. spinulosa seeds under both light and dark conditions. In contrast, light has not been considered important in the germination process for Zostera japonica (Bigley 1981) and $Z$. marina (Tutin 1938, Hootsmans et al. 1987, Harrison 1991, Moore et al. 1993).

Scarification of the seed coat resulted in increased germination rates for Zostera marina (Harrison 1991), $Z$. noltii (Loques et al. 1990), and $Z$. capricorni (Conacher et al. 1994b), suggesting some form of physical dormancy. These studies also found an interaction between salinity and scarification, with germination increasing at lower salinities. Removal of the seed coat of Cymodocea nodosa resulted in increased germination at a lower salinity $(20 \%)$ than a higher one $(38 \%)$ (Caye et al. 1992). McMillan (1987, 1988b) and Birch (1981) found no effect of seed coat removal for Halophila engelmanii, $H$. decipiens, and $H$. spinulosa.

Hormones can influence seed germination in terrestrial plants through either stimulating seed germination (e.g. gibberellic acid, Hilhorst \& Toorop 1997; thiourea, Conacher et al. 1994b) or preventing the termination of dormancy (e.g. abscissic acid, Hilhorst \& Karssen 1992). While a $1 \mathrm{ppm}$ solution of gibberellin $\left(\mathrm{GA}_{7}\right.$ and $\left.\mathrm{KNO}_{3}\right)$ had no effect on Zostera noltii seeds (Loques et al. 1990), more concentrated solutions of gibberellin (50 ppm, $\mathrm{GbA}_{3}$ and $\mathrm{KNO}_{3}$ ) and thiourea $(50 \mathrm{ppm})$ promoted germination of $Z$. capricorni (Conacher et al. 1994b).

One factor common to many of the above studies is that they were conducted in either small aquaria or petri dishes without sediment and did not report oxygen concentrations (Appendix 1). Oxygen levels or some other property of sediments may be the most important factor affecting seed germination (Kawasaki 1993, Moore et al. 1993, Brenchley \& Probert 1998). Moore et al. (1993) showed faster germination of Zostera marina seeds held in both sediments with no oxygen (as measured by redox potential) and vials with water where oxygen was removed compared to seeds held in similar vials with oxygen. Kawasaki et al. (1988) and Kawasaki (1993) also showed that $Z$. marina seed germination was promoted by either covering seeds with sediment or placing them in water at very low dissolved oxygen levels (below $1 \mathrm{ppm}$ ), suggesting a reducing environment was also important for this species. Brenchley \& Probert (1998) found similar results for $Z$. capricorni with little apparent difference in seeds held at 2 salinities ( 15 and $30 \%$ ). In contrast, Churchill (1992) found that seeds of $Z$. marina germinated and retained under anaerobic conditions did not develop properly. Hootsmans et al. (1987) also found little survival of $Z$. marina seeds after $30 \mathrm{~d}$ under anaerobic conditions. Here, seeds were covered with some form of organic material for 1 mo, which may have resulted in toxic sulfide conditions (not mea- 
sured) that may not have reflected natural conditions. The phenomenon of germination in anoxic environments is common for both seeds and tubers in other rooted submersed aquatic plants such as Potamogeton, Hydrilla, and Najas (Sculthorpe 1967, van Vierssen 1982, Spencer \& Ksander 1997).

Based on these data, we infer that the variation in timing of seed germination in the field noted in a number of studies results from the interaction between temperature and sediment oxygen levels (i.e. the depth at which a seed is buried). Steep biogeochemical gradients found in the sedimentary environment (Berner 1980, Moriarity \& Boon 1989, Woodin et al. 1998) where seagrass seeds are deposited may be a key to understanding forcing functions in the germination history of seagrass species that have some delay between seed release and seed germination. Seeds at different burial depths, at the scale of millimeters, will experience significant changes in these parameters. We also suggest that photoperiod will not influence buried seeds and that salinity, a factor often implicated as a major determinant influencing germination, especially low salinities, may need to be re-examined. Additionally, the lack of extensive information on internal physiological cues (e.g. hormones, enzymes) may limit our understanding of critical germination factors.

\section{SEED GERMINATION RESEARCH: FUTURE DIRECTIONS}

Achieving a fundamental understanding of the ecology and population biology of a given seagrass species requires understanding of its seed biology and ecology. Despite some early pioneering work in seagrass seed biology for Zostera marina (Taylor 1957a,b), little substantive research has been done for the majority of species. However, in light of the growing concerns about anthropogenic influences on the survival of seagrass populations worldwide (Short \& Wyllie-Echeverria 1996), conservation of individual species will demand elucidation of the contribution of seeds to population maintenance and creation of new beds. This work must include basic germination ecology.

Although our review has highlighted the lack of this basic work for many seagrass species (Table 2), it also suggests that previous work be re-examined in light of recent research suggesting that factors intrinsic to sediments, especially sediment oxygen levels (redox potentials), may be the most important ones influencing germination processes for some species (Churchill 1983, Moore et al. 1993, Brenchley \& Probert 1998).

Most seagrass seed germination experiments in the literature have incorporated 1 or more of the following conditions that may have potentially compromised the experimental design: the transfer of seeds from sediments to water (change in redox potential), aerial transport of seeds from distant populations (change in temperature), sterilization, atypical storage conditions, and germination experiments conducted in petri dishes without sediment. Few experiments measure oxygen concentration or include oxygen level as a variable. As environmental stratification (cold) has been found to be important for some terrestrial species. (Baskin \& Baskin 1998), it is important that there is no experimenter-created environmental stratification (e.g. transporting seeds on ice) in addition to the germination treatments being tested.

Basic work should follow guidelines established in Baskin \& Baskin (1998) for 'ecologically meaningful' studies. These guidelines include collecting mature seeds and using intact seeds immediately after harvesting and neither scarifying nor soaking seeds in disinfectants or acid prior to the experiment. Maintaining conditions as close to the natural environment as possible is critical for minimizing experiment-induced biases. Replicated, statistically defensible experiments should be conducted either in situ or under conditions that simulate natural conditions, and seeds not used should be stored under natural or simulated conditions (e.g. retained in mesh or burlap bags [Harwell \& Orth 1999] under field conditions). Batch seed experiments should be conducted keeping in mind the inherent variability in seed characteristics (e.g. size, coat thickness, color; Arasaki 1950, Fukuda \& Yasuie 1981, Takaba 1985, Harrison 1991).

We suggest that future work concentrate on addressing the following questions:

\section{Dormancy}

-Does true dormancy exist for seagrass species, and if so, is it environmentally controlled or a property of the seed itself (i.e. organic)?

-If dormancy is organically controlled, is it endogenous (characteristic of the embryo) or exogenous (characteristic of structures such as the seed coat)?

Seed banks

- To what extent do persistent or transient seed banks exist for a given species or between populations of a single species?

-What are the spatial (horizontal and vertical/depth) and temporal characteristics of seed banks?

-What are the relationships between seed bank composition and aboveground community composition in multi-species seagrass ecosystems (e.g. communities in Asia and Australia)?

Seed characteristics

-Are there relationships between size of seed, thickness of seed coat and dormancy, seed bank characteristics, and factors influencing germination? 


\section{Germination}

-What is a standard definition of 'germination' that future work can be based upon as a common reference?

- Is sediment oxygen level concentration a critical, but often overlooked, factor influencing germination?

- How deep in the sediment can a buried seed germinate and still develop into a viable plant?

-What are the evolutionary relationships in germination requirements to seagrass ancestors?

Keys to the above questions in seagrass research efforts rest not just in the links to the terrestrial and freshwater realm but in the innovative experiments yet to be conducted. Reciprocal transplant experiments of seeds of a species across latitudinal gradients may pro- vide answers to dormancy and seed bank questions. Most critically, as researchers begin to focus on conservation and restoration, seed work may figure prominently in landscape level issues regarding protected marine or estuarine reserves, patch dynamics, metapopulation analyses, and habitat fragmentation as well as basic population biology (Montalvo et al. 1997).

Acknowledgements. We would like to thank M. L. Cambridge, H. Kirkman, E. W. Koch, J. Kuo, G. Pergent, P. J. Ralph, S. Wyllie-Echeverria and an anonymous reviewer for constructive comments on earlier drafts of this manuscript This project was initiated as part of a class exercise for MS 656 Seagrass Ecosystems. This is contribution No. 2313 from the Virginia Institute of Marine Science, College of William and Mary.

Appendix 1. Literature summary of factors studied in seed bank, dormancy, and germination experiments in seagrasses. We report whether the study was experimental $(E)$ or observational $(O)$; conducted in a field $(F)$ or laboratory $(L)$ setting; conducted with sediments $(S)$ or water $(W)$; and whether or not the study focused on seed bank characteristics, seed dormancy, or seed ger-

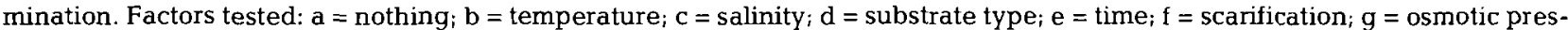

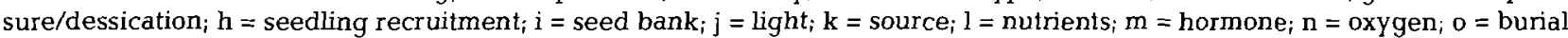
depth $_{i} \mathrm{p}=$ color; $q=$ planting treatment; $\mathrm{r}=$ disturbance; $\mathrm{NA}=$ not available $;-=$ not applicable $;$ Both $=$ study conducted (in part or whole) under both conditions

\begin{tabular}{|c|c|c|c|c|c|c|c|c|}
\hline Taxon & $\mathrm{E} / \mathrm{O}$ & $\mathrm{F} / \mathrm{L}$ & $\mathrm{S} / \mathrm{W}$ & $\begin{array}{l}\text { Seed } \\
\text { bank }\end{array}$ & Dormancy & Germination & Source & $\begin{array}{c}\text { Factors } \\
\text { tested }\end{array}$ \\
\hline \multicolumn{9}{|l|}{ Cymodoceacea } \\
\hline Cymodocea nodosa & $\mathrm{O}$ & $\mathrm{F}$ & $\mathrm{S}$ & $\mathrm{Y}$ & $\mathrm{N}$ & $\mathrm{Y}$ & Caye \& Meinesz (1985) & $\mathrm{a}$ \\
\hline Cymodocea nodosa & $\mathrm{E}$ & $\mathrm{L}$ & W & $\mathrm{N}$ & $\mathrm{N}$ & $\mathrm{Y}$ & Caye \& Meinesz (1986) & $b, c$ \\
\hline Cymodocea nodosa & Both & Both & Both & $\mathrm{N}$ & $\mathrm{N}$ & $\mathrm{Y}$ & Pirc et al. $(1986)$ & $b, d$ \\
\hline Cymodocea nodosa & $E$ & L & W & $\mathrm{N}$ & $\mathrm{N}$ & $\mathrm{Y}$ & Buia \& Mazzella (1991) & $\mathrm{e}$ \\
\hline Cymodocea nodosa & $\mathrm{E}$ & $\mathrm{L}$ & W & $\mathrm{N}$ & $\mathrm{Y}$ & $\mathrm{Y}$ & Caye et al. (1992) & $c_{,} \mathrm{f}, \mathrm{g}$ \\
\hline Cymodocea nodosa & $\mathrm{O}$ & $\mathrm{F}$ & $\mathrm{s}$ & $\mathrm{Y}$ & $\mathrm{N}$ & $\mathrm{Y}$ & Terrados (1993) & h \\
\hline Cymodocea nodosa & $\mathrm{O}$ & $\mathrm{F}$ & $S$ & $\mathrm{~N}$ & $\mathrm{~N}$ & $\mathrm{Y}$ & Reyes et al. (1995) & e \\
\hline Cymodocea rotundata & Both & Both & $\mathrm{S}$ & $\mathrm{Y}$ & $\mathrm{N}$ & $\mathrm{Y}$ & McMillan et al. (1982) & I \\
\hline Halodule uninervis & $\mathrm{E}$ & $\mathrm{L}$ & $\mathrm{W}$ & $N$ & $\mathrm{~N}$ & $\mathrm{Y}$ & McMillan (1991) & e \\
\hline Halodule uninervis & $\mathrm{O}$ & $\mathrm{F}$ & - & $\mathrm{Y}$ & $\mathrm{N}$ & $\mathrm{N}$ & Inglis (2000) & $\mathrm{i}$ \\
\hline Halodule wrightii & $\mathrm{E}$ & $\mathrm{L}$ & $w$ & $\mathrm{Y}$ & $\mathrm{Y}$ & $\mathrm{Y}$ & McMillan (1981) & $c, e$ \\
\hline Halodule wrightii & $\mathrm{E}$ & $\mathrm{L}$ & W & $\mathrm{N}$ & $\mathrm{N}$ & $\mathrm{Y}$ & McMillan (1983a) & $\mathrm{e}$ \\
\hline Halodule wrightii & $\mathrm{O}$ & $\mathrm{F}$ & - & $\mathrm{Y}$ & $\mathrm{N}$ & $\mathrm{N}$ & McMillan (1985) & $\mathrm{i}$ \\
\hline Halodule wrightii & $\mathrm{E}$ & $\mathrm{L}$ & W & $\mathrm{N}$ & $\mathrm{N}$ & $\mathrm{Y}$ & McMilIan (1991) & e \\
\hline Syringodium filiforme & E & $\mathrm{L}$ & W & $\mathrm{Y}$ & $\mathrm{Y}$ & $\mathrm{Y}$ & McMillan (1981) & $\mathrm{b}, \mathrm{c}, \mathrm{e}$ \\
\hline Syringodium filiforme & $\mathrm{E}$ & $\mathrm{L}$ & $\mathrm{W}$ & $\mathrm{N}$ & $\mathrm{N}$ & $\mathrm{Y}$ & McMillan (1983a) & $\mathrm{e}$ \\
\hline Syringodium filiforme & $\mathrm{O}$ & $\mathrm{F}$ & - & $\mathrm{Y}$ & $\mathrm{N}$ & $\mathrm{N}$ & McMillan (1985) & $\mathrm{i}$ \\
\hline Syringodium filiforme & $\mathrm{E}$ & $\mathrm{L}$ & W & $\mathrm{N}$ & $\mathrm{N}$ & $\mathrm{Y}$ & McMillan (1991) & e \\
\hline \multicolumn{9}{|l|}{ Hydrocharitaceae } \\
\hline Halophila decipiens & E & $\mathrm{L}$ & W & $\mathrm{Y}$ & $\mathrm{N}$ & $\mathrm{Y}$ & McMillan (1988b) & $e, k$ \\
\hline Halophila decipiens & $E$ & $\mathrm{~L}$ & Both & $\mathrm{N}$ & $\mathrm{Y}$ & $\mathrm{Y}$ & McMillan (1988c) & d,e \\
\hline Halophila decipiens & $\mathrm{E}$ & $\mathrm{L}$ & W & $\mathrm{Y}$ & $\mathrm{N}$ & $\mathrm{Y}$ & McMillan \& Soong (1989) & $e_{j} j$ \\
\hline Halophila decipiens & $\mathrm{E}$ & $\mathrm{L}$ & W & $\mathrm{N}$ & $\mathrm{N}$ & $\mathrm{Y}$ & McMillan (1991) & $e, j$ \\
\hline Halophila decipiens & $\mathbf{E}$ & $\mathrm{L}$ & W & $\mathrm{N}$ & $\mathrm{N}$ & $\mathrm{Y}$ & Kuo \& Kirkman (1995) & e \\
\hline Halophila engelmanni & $\mathrm{O}$ & $\mathrm{F}$ & - & $\mathrm{Y}$ & $\mathrm{N}$ & $\mathrm{N}$ & McMillan (1986) & $\mathrm{i}$ \\
\hline Halophila engelmanni & $\mathbf{E}$ & Both & $\mathrm{W}$ & $\mathrm{Y}$ & $\mathrm{N}$ & $\mathrm{Y}$ & McMillan (1988a) & $e_{\mathbf{j}} \mathbf{j}$ \\
\hline Halophila engelmanni & $\mathrm{E}$ & $\mathrm{L}$ & W & $\mathrm{N}$ & $\mathrm{N}$ & $\mathrm{Y}$ & Jewett-Smith \& McMillan (1990) & $\mathrm{d}$ \\
\hline Halophila engelmanni & $\mathrm{E}$ & $\mathrm{L}$ & W & $N$ & $\mathrm{~N}$ & $\mathrm{Y}$ & McMillan (1991) & $e, j$ \\
\hline Halophila ovalis & $E$ & L & $W$ & $\mathrm{Y}$ & $N$ & $\mathrm{Y}$ & Kuo \& Kirkman (1992) & $\mathrm{e}$ \\
\hline Halophila spinulosa & $\mathrm{O}$ & $\mathrm{L}$ & Both & $\mathrm{N}$ & $\mathrm{Y}$ & $\mathrm{Y}$ & Birch (1981) & $f, j, l$ \\
\hline Halophila tricostata & $\mathrm{E}$ & $\mathrm{L}$ & W & $\mathrm{N}$ & $\mathrm{N}$ & $\mathrm{Y}$ & Kuo et al. (1993) & $\mathrm{e}$ \\
\hline Halophila beccarii & $\mathrm{O}$ & $\mathrm{F}$ & - & $\mathrm{Y}$ & $\mathrm{N}$ & $\mathrm{N}$ & Zakaria et al. (1999) & $\mathrm{i}$ \\
\hline
\end{tabular}


Appendix 1 (continued)

\begin{tabular}{|c|c|c|c|c|c|c|c|c|}
\hline Taxon & $\mathrm{E} / \mathrm{O}$ & $\mathrm{F} / \mathrm{L}$ & $\mathrm{S} / \mathrm{W}$ & $\begin{array}{l}\text { Seed } \\
\text { bank }\end{array}$ & Dormancy & Germination & Source & $\begin{array}{c}\text { Factors } \\
\text { tested }\end{array}$ \\
\hline \multicolumn{9}{|l|}{ Zosteraceae } \\
\hline Phyllospadix iwatensis & $E$ & $\mathrm{~L}$ & W & $N$ & $N$ & $\mathrm{Y}$ & Kuo et al. (1990) & e \\
\hline Phyllospadix scouleri & $E$ & $\mathrm{~L}$ & - & $\mathrm{N}$ & $\mathrm{N}$ & $\mathrm{Y}$ & Turner (1983) & $\mathrm{h}$ \\
\hline Phyllospadix scouleri & $E$ & $\mathrm{~L}$ & - & $\mathrm{N}$ & $\mathrm{N}$ & $\mathrm{Y}$ & Turner (1985) & $\mathrm{h}$ \\
\hline Phyllospadix torreyi & $\mathrm{E}$ & $\mathrm{L}$ & w & $\mathrm{N}$ & $Y$ & $\mathrm{Y}$ & Reed et al. (1998) & $e, m$ \\
\hline Zostera capensis & $E$ & $\mathrm{~L}$ & W & $\mathrm{N}$ & $\mathrm{N}$ & $\mathrm{Y}$ & Edgecumbe (1980) & $b, c, e, j$ \\
\hline Zostera capricorni & $E$ & $L$ & - & $N$ & $\mathrm{Y}$ & $N$ & Murray \& Larkum (1992) & g \\
\hline Zostera capricorni & $\mathrm{O}$ & $\mathrm{F}$ & $\mathrm{S}$ & $\mathrm{Y}$ & $\mathrm{N}$ & $\mathrm{N}$ & Conacher et al. (1994a) & i \\
\hline Zostera capricorni & $\mathrm{E}$ & $\mathrm{L}$ & W & $\mathrm{N}$ & $N$ & $\mathrm{Y}$ & Conacher et al. (1994b) & $\mathrm{b}, \mathrm{c}, \mathrm{f}, \mathrm{l}, \mathrm{m}$ \\
\hline Zostera capricorni & $\mathrm{O}$ & $\mathrm{F}$ & W & $\mathrm{Y}$ & $\mathrm{N}$ & $\mathrm{Y}$ & Peterken \& Conacher (1997) & e \\
\hline Zostera capricorni & E & $\mathrm{L}$ & W & $\mathrm{N}$ & $\mathrm{N}$ & $\mathrm{Y}$ & Brenchley \& Probert (1998) & $\mathbf{b}, \mathbf{c}, \mathbf{n}$ \\
\hline Zostera japonica & Both & Both & Both & $\mathrm{Y}$ & $\mathrm{Y}$ & $\mathrm{Y}$ & Bigley (1981) & $b, c, e, j, n, o$ \\
\hline Zostera marina & E & $\mathrm{L}$ & W & $N$ & $\mathrm{~N}$ & $\mathrm{Y}$ & Tutin (1938) & $\mathrm{b}, \mathrm{c}, \mathrm{e}$ \\
\hline Zostera marina & $\mathrm{O}$ & $\mathrm{F}$ & $\mathrm{S}$ & $\mathrm{N}$ & $\mathrm{N}$ & $\mathrm{Y}$ & Addy (1947) & e \\
\hline Zostera marina & $\mathrm{E}$ & $\mathrm{L}$ & $\mathrm{W}$ & $\mathrm{N}$ & $\mathrm{N}$ & $\mathrm{Y}$ & Arasaki (1950) & $\mathrm{b}, \mathrm{c}, \mathrm{p}$ \\
\hline Zostera marina & 0 & - & W & $N$ & $\mathrm{~N}$ & $\mathrm{Y}$ & Taylor (1957b) & a \\
\hline Zostera marina & Both & Both & W & $\mathrm{N}$ & $N$ & $\mathrm{Y}$ & Phillips (1972) & $c, e$ \\
\hline Zostera marina & E & $\mathrm{L}$ & NA & $N$ & $N$ & $\mathrm{Y}$ & Hade et al. (1974) & $b, c$ \\
\hline Zostera marina & $E$ & Both & Both & $\mathrm{N}$ & $Y$ & $Y$ & Hade et al. (1975a) & $e, q$ \\
\hline Zostera marina & $E$ & F & $\mathrm{S}$ & $N$ & $N$ & $Y$ & Hade et al. (1975b) & $e, q$ \\
\hline Zostera manina & $\mathrm{E}$ & $\mathrm{F}$ & $S$ & $\mathrm{~N}$ & $N$ & $\mathrm{Y}$ & Hade et al. (1976) & $\mathrm{e}, \mathrm{q}$ \\
\hline Zostera marina & $\mathrm{E}$ & $\mathrm{L}$ & Both & $\mathrm{N}$ & $\mathrm{N}$ & $\mathrm{Y}$ & De Cock (1977) & h \\
\hline Zostera marina & $E$ & $L$ & W & $N$ & $N$ & $Y$ & Lamounette (1977) & $b, c, e, f, g$ \\
\hline Zostera marina & E & $\mathrm{L}$ & W & $\mathrm{N}$ & $\mathrm{N}$ & $\mathrm{Y}$ & Churchill \& Riner (1978) & $\mathrm{e}$ \\
\hline Zostera marina & $E$ & $\bar{L}$ & $\mathrm{~S}$ & $\mathrm{~N}$ & $\mathrm{~N}$ & $\mathrm{Y}$ & Keddy \& Patriquin (1978) & $b, c, e, f, g$ \\
\hline Zostera marina & $E$ & $\mathrm{~F}$ & $S$ & $\mathrm{~N}$ & $\mathrm{~N}$ & $\mathrm{Y}$ & Yasuie \& Fukuda (1980) & $\mathrm{e}, \mathrm{q}$ \\
\hline Zostera marina & $E$ & $\mathrm{~F}$ & $\mathrm{~S}$ & $N$ & $\mathrm{~N}$ & $\mathrm{Y}$ & Fukuda \& Yasuie [1981] & $\mathrm{m}, \mathrm{p}$ \\
\hline Zostera marina & $E$ & $\mathrm{~F}$ & $\mathrm{~S}$ & $\mathrm{~N}$ & $\mathrm{~N}$ & $\mathrm{Y}$ & Yasuie \& Fukuda (1981) & $\mathrm{i}^{2}$ \\
\hline Zostera marina & $E$ & $\mathrm{~L}$ & $\mathrm{~S}$ & $N$ & $\mathrm{~N}$ & $\mathrm{Y}$ & Fukuda \& Tsuchiya (1982) & $\mathrm{d}$ \\
\hline Zostera marina & $E$ & $\mathrm{~F}$ & $\mathrm{~S}$ & $\mathrm{~N}$ & $\mathrm{~N}$ & $\mathrm{Y}$ & Churchill (1983) & $\mathrm{e}$ \\
\hline Zostera marina & $E$ & $\mathrm{~L}$ & W & $\mathrm{N}$ & $\mathrm{N}$ & $\mathrm{Y}$ & McMillan (1983b) & $c, g$ \\
\hline Zostera marina & $E$ & $\mathrm{~F}$ & W & $\mathrm{N}$ & $\mathrm{N}$ & $\mathrm{Y}$ & Orth \& Moore (1983) & $\mathrm{e}, \mathrm{k}$ \\
\hline Zostera marina & $E$ & $\mathrm{~L}$ & W & $N$ & $N$ & $\mathrm{Y}$ & Phillips et al. (1983) & $\mathrm{b}, \mathrm{c}, \mathrm{k}$ \\
\hline Zostera marina & $\bar{E}$ & $\bar{F}$ & $\mathrm{~S}$ & $\mathrm{~N}$ & N & $\mathrm{Y}$ & Fukuda et al. (1984) & q \\
\hline Zostera marina & $\mathrm{O}$ & $\mathrm{F}$ & W & $\mathrm{Y}$ & $\mathrm{N}$ & $\mathrm{N}$ & Gates (1984) & i \\
\hline Zostera marina & 0 & $\mathrm{~F}$ & $S$ & $\mathrm{Y}$ & $N$ & $Y$ & Robertson \& Mann (1984) & $e, g$ \\
\hline Zostera marina & $\mathrm{O}$ & $\mathrm{F}$ & $\mathrm{S}$ & $\mathrm{Y}$ & $N$ & $\mathrm{Y}$ & Bodnar (1985) & e \\
\hline Zostera marina & $\mathrm{E}$ & $\mathrm{L}$ & $S$ & $\mathrm{~N}$ & $\mathrm{~N}$ & $\mathrm{Y}$ & Kawasaki et al. (1985) & $\mathrm{b}$ \\
\hline Zostera marina & $\bar{E}$ & $\bar{L}$ & NA & $N$ & $N$ & $\mathrm{Y}$ & Takaba (1985) & $\mathrm{p}$ \\
\hline Zostera marina & $\bar{E}$ & F & $\mathrm{S}$ & $N$ & $N$ & $\mathrm{Y}$ & Fukuda (1987) & o \\
\hline Zostera marina & $\mathrm{E}$ & $\mathrm{F}$ & $\mathrm{S}$ & $N$ & $N$ & $\mathrm{Y}$ & Fukuda \& Sato (1987a) & $k, q$ \\
\hline Zostera marina & $E$ & $\mathrm{~F}$ & $\mathrm{~S}$ & $\mathrm{~N}$ & $N$ & $\mathrm{Y}$ & Fukuda \& Sato (1987b) & NA \\
\hline Zostera marina & $\mathrm{E}$ & F & $\mathrm{S}$ & $\mathrm{N}$ & $\mathrm{N}$ & $\mathrm{Y}$ & Fukuda \& Sato $(1987 c)$ & $\mathrm{q}$ \\
\hline Zostera marina & Both & Both & Both & $\mathrm{Y}$ & $\mathrm{N}$ & $\mathrm{Y}$ & Hootsmans et al. (1987) & $c, g, j, n$ \\
\hline Zostera marina & $\mathrm{E}$ & L & NA & $N$ & $\mathrm{~N}$ & $\mathrm{Y}$ & Kawasaki (1987) & $\mathrm{b}$ \\
\hline Zostera marina & $\bar{E}$ & $\mathrm{~L}$ & $\mathrm{~S}$ & $\mathrm{~N}$ & $\mathrm{~N}$ & $\mathrm{Y}$ & Kawasaki et al. (1988) & $e, o$ \\
\hline Zostera marina & $E$ & $\mathrm{~L}$ & W & $N$ & $\mathrm{Y}$ & $\mathrm{Y}$ & Harrison (1991) & $b, c, e, f, p$ \\
\hline Zostera marina & $E$ & L & Both & $N$ & $\mathrm{~N}$ & $\mathrm{Y}$ & Chur chill (1992) & $\mathrm{n}$ \\
\hline Zostera marina & $E$ & L & - & $\mathrm{N}$ & $Y$ & $N$ & Murray \& Larkum (1992) & $g$ \\
\hline Zostera marina & $\mathrm{O}$ & $\mathrm{F}$ & w & $\mathrm{Y}$ & $\mathrm{N}$ & $\mathrm{Y}$ & Harrison (1993) & $\mathrm{h}, \mathrm{i}$ \\
\hline Zostera marina & $E$ & $\mathrm{~L}$ & Both & $\mathrm{N}$ & $\hat{N}$ & $\mathrm{Y}$ & Kawasaki (1993) & $b, c, n, o$ \\
\hline Zostera marina & $E$ & $\mathrm{~L}$ & Both & $N$ & $N$ & $\mathrm{Y}$ & Moore et al. (1993) & $\mathrm{j}, \mathrm{n}, \mathrm{o}$ \\
\hline Zostera marina & $\mathrm{O}$ & $\mathrm{F}$ & $\mathrm{S}$ & $\mathrm{N}$ & $\mathrm{N}$ & $\mathrm{N}$ & Olesen \& Sand-Jensen (1994) & $\mathrm{h}$ \\
\hline Zostera marina & $E$ & $\mathrm{~F}$ & $\mathrm{~S}$ & $\mathrm{~N}$ & $N$ & $\mathrm{Y}$ & Ruckelshaus [1994] & $k, q$ \\
\hline Zostera marina & $E$ & $\mathrm{~L}$ & W & $N$ & $N$ & $\mathrm{Y}$ & van Lent \& Verschuure (1995) & $c, e^{2}$ \\
\hline Zostera marina & $\mathrm{E}$ & Both & $\mathrm{S}$ & $N$ & $\mathrm{~N}$ & $\mathrm{Y}$ & Harwell \& Orth (1999) & $0, \mathrm{q}$ \\
\hline Zostera marina & O & $\mathrm{F}$ & - & Y & $\mathrm{N}$ & $\mathrm{N}$ & Santamaría-Gallegos et al. (1999) & ) $\quad \mathrm{i}$ \\
\hline Zostera noltii & Both & Both & Both & $\mathrm{Y}$ & $\mathrm{N}$ & $\mathrm{Y}$ & Hootsmans et al. (1987) & $c, g, j, n$ \\
\hline Zostera noltii & $\mathrm{O}$ & $\mathrm{F}$ & $\mathrm{S}$ & $\mathrm{Y}$ & $\mathrm{N}$ & $\mathrm{N}$ & Loques et al. (1988) & $i$ \\
\hline Zostera noltii & $E$ & $\mathrm{~L}$ & W & $\mathrm{N}$ & $\mathrm{N}$ & $\mathrm{Y}$ & Loques et al. (1990) & $\mathrm{b}, \mathrm{c}, \mathrm{f}, \mathrm{m}$ \\
\hline Zostera noltii & $\mathrm{O}$ & $\mathrm{F}$ & $\mathrm{S}$ & $\mathrm{N}$ & $\mathrm{Y}$ & $\mathrm{N}$ & Buia \& Mazzella (1991) & $\mathrm{e}$ \\
\hline Zostera noltii & $\mathrm{O}$ & $\mathrm{F}$ & W & $\mathrm{N}$ & $\mathrm{N}$ & Y & Goubin \& Loques (1991) & $\mathrm{e}$ \\
\hline Zostera noltii & $\mathrm{O}$ & $\mathrm{F}$ & W & $\mathrm{Y}$ & $\mathrm{N}$ & $\mathrm{Y}$ & Harrison (1993) & $\mathrm{i}$ \\
\hline
\end{tabular}




\section{LITERATURE CITED}

Addy CE (1947) Germination of eelgrass seed. J Wildl Manag $11: 279$

Arasaki M (1950) Studies on the ecology of Zostera marina and Zostera nana. II. Bull Jpn Soc Sci Fish 16:70-76 (in Japanese)

Baskin CC, Baskin JM (1998) Seeds: ecology, biogeography, and evolution of dormancy and germination. Academic Press, New York

Berner RA (1980) Early diagenesis: a theoretical approach. Princeton University Press, Princeton, NJ

Bewley JD (1997) Seed germination and dormancy. Plant Cell 9:1055-1066

Bigley RE (1981) The population biology of two intertidal seagrasses, Zostera japonica and Ruppia maritima, at Roberts Bank, British Columbia. MSc thesis, University of British Columbia, Vancouver, BC

Birch WR (1981) Morphology of germinating seeds of the seagrass Halophila spinulosa (R.Br.) Aschers (Hydrocharitaceae). Aquat Bot 11:79-90

Bodnar PJ Jr (1985) A field study on seed production and sediment seed reserves in a Long Island population of Zostera marina L. MS thesis, Adelphi University, Garden City, NY

Brenchley JL, Probert RJ (1998) Seed germination responses to some environmental factors in the seagrass Zostera capricorni from eastern Australia. Aquat Bot 62:177-188

Buia MC, Mazzella L (1991) Reproductive phenology of the Mediterranean seagrasses Posidonia oceanica (L.) Delile, Cymodosa nodosa (Ucria) Aschers., and Zostera noltii Hornem. Aquat Bot 40:343-362

Caye G, Meinesz A (1985) Observations on the vegetative development, flowering and seeding of Cymodocea nodosa (Ucria) Ascherson on the Mediterranean coasts of France. Aquat Bot 22:277-289

Caye G, Meinesz A (1986) Experimental study of seed germination in the seagrass Cymodocea nodosa. Aquat Bot 26: 79-87

Caye G, Bulard C, Meinesz A, Loques F (1992) Dominant role of seawater osmotic pressure on germination in Cymodocea nodosa. Aquat Bot 42:187-193

Chambers JC, MacMahon JA (1994) A day in the life of a seed: movements and fates and their implications for natural and managed systems. Annu Rev Ecol Syst 25: 263-292

Churchill AC (1983) Field studies on seed germination and seedling development in Zostera marina L. Aquat Bot 9: 201-220

Churchill AC (1992) Growth characteristics of Zostera marina seedlings under anaerobic conditions. Aquat Bot 43: 379-392

Churchill AC, Riner MI (1978) Anthesis and seed production in Zostera marina L. from Great South Bay, New York, U.S.A. Aquat Bot 4:83-93

Coles RG, Lee Long WJ, Squire BA, Squire LC, Bibby JM (1987) Distribution of seagrass and associated juvenile commercial penaeid prawns in northeastern Queensland waters. Aust J Mar Freshw Res 38:103-119

Conacher CA, Poiner IR, O'Donohue M (1994a) Morphology, flowering and seed production of Zostera capricorni Aschers. in subtropical Australia. Aquat Bot 49:33-46

Conacher CA, Poiner IR, Butler J, Pun S, Tree DJ (1994b) Germination, storage and viability testing of seeds of Zostera capricorni Aschers. Aquat Bot 49:47-58

Dawes CJ, Andorfer J, Rose C, Uranowski C, Ehringer N (1997) Regrowth of the seagrass Thalassia testudinum into propellor scars. Aquat Bot 59:139-155
De Cock AWAM (1977) Culture of Zostera marina L. in the laboratory. Aquaculture 12:279-281

den Hartog C (1970) The seagrasses of the world. NorthHolland, Amsterdam

Edgar G (1990) The influence of plant structure on the species richness, biomass and secondary production of macrofaunal assemblages associated with Western Australia seagrass beds. J Exp Mar Biol Ecol 137:215-240

Edgecumbe DJ (1980) Some preliminary observations on the submerged aquatic Zostera capensis Setchell. S Afr J Bot 46(1):53-66

Fenner M (1995) Ecology of seed-banks. In: Kigel J, Galili G (eds) Seed development and germination. Marcel Dekker, Inc, New York, p 507-528

Fonseca MS, Kenworthy WJ, Thayer GW (1998) Guidelines for the conservation and restoration of seagrasses in the United States and adjacent waters. NOAA Coastal Ocean Program Decision Analysis Series No 12. NOAA Coastal Ocean Office, Silver Spring, MD

Fredette TJ, Diaz RJ, van Montfrans J, Orth RJ (1990) Secondary production within a seagrass bed (Zostera marina and Ruppia maritima) in lower Chesapeake Bay. Estuaries $13: 431-440$

Fukuda T (1987) Development of the techniques for marine macrophyte (Zostera marina) bed creation VII. Depth of seeding. Okayama Suishi Ho 2:32-34 (in Japanese)

Fukuda T, Sato $J$ (1987a) Development of the techniques for marine macrophyte [Zostera marina] bed creation. VI. Differences of germination rate among the density of seeding and between the seeds obtained from different places. Okayama Suishi Ho 2:27-31 (in Japanese)

Fukuda T, Sato J (1987b) Collected data on the development of the techniques for marine macrophyte (Zostera marina) bed creation: especially germination of remaining seeds, differences of subtrata, and changes of vegetative shoot and flowering turion. Okayama Suishi Ho 2:180-194 (in Japanese)

Fukuda T, Sato J (1987c) Practice of Zostera bed creation at Hinase. Okayama Suishi Ho 2:195-200 (in Japanese)

Fukuda T, Tsuchiya Y (1982) On the substratum and others in the raising of eelgrass Zostera marina seedlings. Okayama Suishi Jiho 56:142-146 (in Japanese)

Fukuda T, Yasuie S (1981) Reserve and treatment of eelgrass, Zostera marina, seed to the germination. Saibaigiken 10 7-13 (in Japanese)

Fukuda T, Katsutani K, Terashima S (1984) Development of the techniques for marine macrophyte (Zostera marina) bed creation. II. The effect of seeding and creation of sand bed. Okayama Suishi Jiho 58:50-55 (in Japanese)

Gates K (1984) A comparison of two Zostera marina L. seed banks in Great South Bay, New York. MSc thesis, Adelphi University, Garden City, NY

Goubin C, Loques F (1991) Germinating Zostera noltii Hornemann found in the Etang de Diana, Corsica. Aquat Bot 42 $75-79$

Gutterman Y (1994) Strategies of seed dispersal and germination in plants inhabiting deserts. Bot Rev 60(4):373-425

Hade K, Kamijyo Y, Ogawa K, Kunitake K (1974) Research on planting of Zostera marina. I. Cropping of seeds and their germination and growth. Saibaigiken 3:123-131 (in Japanese)

Hade K, Ogawa K, Kunitake K (1975a) Research on planting of Zostera marina. II. Cropping of a great amount of seeds and seedling in the field. Saibaigiken 4:7-13 (in Japanese)

Hade K, Ogawa K, Kunitake K (1975b) Research on planting of Zostera marina. III. Creation of Zostera beds by seedling. Saibaigiken 4:21-26 (in Japanese) 
Hade K, Ogawa K, Kunitake K (1976) Research on planting of Zostera marina. IV. Creation of Zostera beds by seeding and transplanting roots. Saibaigiken 5:17-22 (in Japanese)

Hamrick JL, Lee JM (1987) Effect of soil surface topography and litter cover on the germination, survival and growth of musk thistle (Carduus nutans). Am J Bot 74:451-457

Harrison PG (1991) Mechanisms of seed dormancy in an annual population of Zostera marina (eelgrass) from the Netherlands. Can J Bot 69:1972-1976

Harrison PG (1993) Variations in demography of Zostera marina and Zostera noltii on an intertidal gradient. Aquat Bot 45:63-77

Harwell MC, Orth RJ (1999) Eelgrass (Zostera marina L.) seed protection for field experiments and implications for large. scale restoration. Aquat Bot 64:51-61

Heck KL Jr, Nadeau DA, Thomas R (1997) The nursery role of seagrass beds. Gulf Mex Sci 15(1):50-54

Hilhorst HWM, Karssen CM (1992) Seed dormancy and germination: the role of abscisic acid and gibberellins and the importance of hormone mutants. Plant Growth Regul 11: $225-238$

Hilhorst HWM, Toorop PE (1997) Review on dormancy, germinability and germination in crop and weed seeds. Adv Agron 61:111-165

Hootsmans MJM, Vermaat JE, van Vierssen W (1987) Seedbank development, germination and early seedling survival of two seagrass species from the Netherlands: Zostera marina L. and Zostera noltii Hornem. Aquat Bot 28:275-285

Inglis GJ (2000) Disturbance-related heterogeneity in the seed banks of a marine angiosperm. J Ecol 88:88-99

Jacobs RPWM, Pierson ES (1981) Phenology of reproductive shoots of eelgrass, Zostera marina L. at Roscoff (France). Aquat Bot 10:45-60

Jewett-Smith J, McMillan C (1990) Germination and seedling development of Halophila engelmannii Aschers. (Hydrocharitaceae) under axenic conditions. Aquat Bot 36 : $167-177$

Kantrud HA (1991) Widgeongrass (Ruppia maritima L.): a literature review. US Fish Wildl Serv Fish Wildl Res 10: $1-58$

Kawasaki Y (1987) Effect of temperature on Zostera marina L. lIl. Change of the life cycle by a rise in temperature. Central Research Institute of Electric Power Industry Report No. U87046 lwatokita Komae-shi (in Japanese)

Kawasaki Y (1993) Effects of some environmental factors on seed germination and seedling growth of Zostera marina L. In: International Workshop on Seagrass Biology, ltominato, 1993 Proceedings. Ocean Research Institute, University of Tokyo, p 28-35

Kawasaki Y, Iituka T, Goto $H$, Terawaki $T$, Shimo S (1985) Effects of temperature on Zostera marina L. 1. Seed germination and seedling development. Central Research Institute of Electric Power Industry Report No. 485028 Iwatokita Komae-shi (in Japanese)

Kawasaki Y, Yamada S, Honda M (1988) Development of technique for marine macrophyte bed creation in the coastal zone near Power Plant -10 . Method for eelgrass (Zostera marina L.) bed creation by seeding. Central Research Institute of Electric Power Industry Report No. 88030 Iwatokita Komae-shi (in Japanese)

Keddy CJ, Patriquin DG (1978) An annual form of eelgrass in Nova Scotia. Aquat Bot 5:163-170

Khan MA, Ungar lA (1997) Effects of thermoperiod on recovery of seed germination of halophytes from saline conditions. Am J Bot 84(2):279-283
Kirkman H, Kuo J [1990) Pattern and process in southern Western Australian seagrasses. Aquat Bot 37:367-382

Kuo J, Kirkman H (1992) Fruits, seeds and germination in the seagrass Halophila ovalis (Hydrocharitaceae). Bot Mar 35: $197-204$

Kuo $J$, Iizumi $\mathrm{H}$, Nilsen BE, Aioi K (1990) Fruit anatomy, seed germination and seedling development in the Japanese seagrass Phyllospadix (Zosteraceae). Aquat Bot 37: $229-245$

Kuo J, Lee Long W, Coles RG (1993) Occurrence and fruit and seed biology of Halophila tricostata Greenway (Hydrocharitaceae). Aust J Mar Freshw Res 44:43-57

Kuo J, Kirkman H (1995) Halophila decipiens Ostenfeld in estuaries of southwestern Australia. Aquat Bot 51:335-340

Kuo J, Kirkman H (1996) Seedling development of selected Posidonia species from southwest Australia. In: Kuo J, Phillips RC, Walker DI, Kirkman H (eds) Seagrass biology: Proceedings of an International Workshop, Rottnest Island Western Australia. Faculty of Science, University of Western Australia, Perth, p 57-64

Lamounette RG (1977) A study of the germination and viability of Zostera marina L. seeds. MSc thesis, Adelphi University, Garden City, NY

Larkum AWD, McComb AJ, Shepherd SA (1989) Biology of seagrasses: a treatise on the biology of seagrasses with special reference to the Australian region. Elsevier, New York

Loques F, Caye G, Meinesz A (1988) Flowering and fruiting of Zostera noltii in Golfe Juan (French Mediterranean). Aquat Bot 32:341-352

Loques F, Caye G, Meinesz A (1990) Germination in the marine phanerogam Zostera noltii Hornemann at Golfe Juan, French Mediterranean. Aquat Bot 38:249-260

Marba N, Walker DI (1999) Growth, flowering, and population dynamics of temperate Western Australian seagrasses. Mar Ecol Prog Ser 184:105-118

McMillan C (1981) Seed reserves and seed germination for two seagrasses, Halodule wrightii and Syringodium filiforme, from the Western Atlantic. Aquat Bot 11:279-296

McMillan C (1983a) Seed germination in Halodule wrightii and Syringodium filiforme from Texas and the U.S. Virgin Islands. Aquat Bot 15:217-220

McMillan C (1983b) Seed germination for an annual form of Zostera marina from the Sea of Cortez, Mexico. Aquat Bot $16: 105-110$

McMillan C (1985) The seed reserve for Halodule wrightij, Syringodium filiforme and Ruppia maritima in Laguna Madre, Texas. Contrib Mar Sci 28:141-149

McMillan C (1986) Fruits and seeds of Halophila engelmannii (Hydrocharitaceae) in Texas. Contrib Mar Sci 29:1-8

McMillan C (1987) Seed germination and seedling morphology of the seagrass, Halophila engelmannii (Hydrocharitaceae). Aquat Bot 28:179-188

McMillan C (1988a) The seed reserve of Halophila engelmannii (Hydrocharitaceae) in Redfish Bay, Texas. Aquat Bot 30:253-259

McMillan C (1988b) Seed germination and seedling development of Halophila decipiens Ostenfeld (Hydrocharitaceae) from Panama. Aquat Bot 31:169-176

McMillan C (1988c) The seed reserve of Halophila decipiens Ostenfeld (Hydrocharitaceae) in Panama. Aquat Bot 31: $177-182$

McMillan C (1991) The longevity of seagrass seeds. Aquat Bot 40:195-198

McMillan C, Soong K (1989) An annual cycle of flowering, fruiting and seed reserve for Halophila decipiens Ostenfeld (Hydrocharitaceae) in Panama. Aquat Bot 34:365-379 
McMillan C, Bridges KW, Kock RL, Falanruw M (1982) Fruit and seedlings of Cymodocea rotundata in Yap, Micronesia. Aquat Bot 14:99-105

Montalvo AM, Williams SL, Rice KJ, Buchmann SL, Cory C, Handel SN, Nabhan SN, Primack R, Robichaux RH (1997) Restoration biology: a population biology perspective. Restor Ecol 5(4):277-290

Moore KA, Orth RJ, Nowak JF (1993) Environmental regulation of seed germination in Zostera marina L. (eelgrass) in Chesapeake Bay: effects of light, oxygen and sediment burial. Aquat Bot 45:79-91

Moriarty DJW, Boon PI (1989) Interactions of seagrasses with sediment and water. In: Larkum AWD, McComb AJ, Shepherd SA (eds) Biology of seagrasses: a treatise on the biology of seagrasses with special reference to the Australian region. Elsevier, New York, p 500-535

Murray DR, Larkum AWD (1992) Nitrogen content of seeds of Zostera capricorni and Zostera marina. Aquat Bot 43 87-91

National Research Council (1995) Understanding marine biodiversity. National Academy Press, Washington, DC

Olesen B, Sand-Jensen K (1994) Patch dynamics of eelgrass Zostera marina. Mar Ecol Prog Ser 106:147-156

Orth RJ (1999) Settling rates of Posidonia coriacea seeds and Posidonia spp. seedling abundance off Rottnest Island Perth, Western Australia. In: Walker DI, Wells FE (eds) The seagrass flora and fauna off Rottnest Island, Western Australia. Western Australia Museum, Perth, p 51-61

Orth RJ, Moore KA (1983) Seed germination and seedling growth of Zostera marina L. (eelgrass) in the Chesapeake Bay. Aquat Bot 15:117-131

Orth RJ, Luckenbach M, Moore KA (1994) Seed dispersal in a marine macrophyte: implications for colonization and restoration. Ecology 75(7): 1927-1939

Peterken CJ, Conacher CA (1997) Seed germination and recolonisation of Zostera capricorni after grazing by dugongs. Aquat Bot 59:333-340

Phillips RC (1972) Ecological life history of Zostera marina L. (eelgrass) in Puget Sound, Washington. PhD thesis, University of Washington

Phillips RC, Grant WS, McRoy CP (1983) Reproductive strategies of eelgrass (Zostera marina L.). Aquat Bot 16:1-20

Piazzi L, Balestri E, Magri M, Cinelli F (1998) Experimental transplanting of Posidonia oceanica (L.) Delile into a disturbed habitat in the Mediterranean Sea. Bot Mar 41: 593-601

Pirc H, Buia MC, Mazzella L (1986) Germination and seedling development of Cymodocea nodosa (Ucria) Ascherson under laboratory conditions and 'in situ'. Aquat Bot 26: 181-188

Reed DC, Holbrook SJ, Solomon E, Anghera M (1998) Studies on germination and root development in the surfgrass Phyllospadix torreyi: implications for habitat restoration. Aquat Bot 62:71-80

Reyes J, Sanson M, Afonso-Carrilla J (1995) Distribution and reproductive phenology of the seagrass Cymodocea nodosa (Ucria) Ascherson in the Canary IsIands. Aquat Bot 50:171-180

Robertson AI, Mann KH (1984) Disturbance by ice and lifehistory adaptations of the seagrass Zostera marina. Mar Biol 80:131-141

Ruckelshaus MH (1994) Ecological and genetic factors affecting population structure in the marine angiosperm, Zostera marina L. PhD thesis, University of Washington

Santamaría-Gallegos N, Sánches-Lizaso JL, Félix-Pico EF (1999) Phenolgy and growth cycle of annual subtidal eeIgrass in a subtropical locality. Aquat Bot 66:329-339
Sargent FJ, Leary TJ, Crewz DW, Kruer CR (1995) Scarring of Florida's seagrasses: assessment and management options. Florida Mar Res Inst Tech Rep. Florida Marine Research Institute, St. Petersburg, FL

Sculthorpe CD (1967) The biology of aquatic vascular plants. St Martin's Press, New York

Short FT, Burdick DM (1996) Quantifying eelgrass habitat loss in relation to housing development and nitrogen loading in Waquoit Bay, Massachussetts. Estuaries 19(3): 730-739

Short FT, Wyllie-Echeverria S (1996) Natural and humaninduced disturbances of seagrasses. Environ Conserv 23(1):17-27

Short FT, Jones GE, Burdick DM (1991) Seagrass decline: problems and solutions. In: Bolton HS (ed) Coastal wetlands. American Society of Civil Engineers, New York, p 439-453

Silberhorn GM, Orth RJ, Moore KA (1983) Anthesis and seed production in Zostera marina L. (eelgrass) from the Chesapeake Bay. Aquat Bot 15:133-144

Simpson GM (1990) Seed dormancy in grasses. Cambridge University Press, New York

Skoglund J (1992) The role of seed banks in vegetation dynamics and restoration of dry tropical ecosystems. J Veg Sci 3:357-360

Spencer DF, Ksander GG (1997) Influence of anoxia on sprouting of vegetative propagules of three species of aquatic plant propagules. Wetlands 17(1):55-64

Takaba M (1985) Studies on the collected seeds of eelgrass, Zostera marina, and germination rate at different collecting and at different seeding depth. Bull Hiroshima Fish Exp Stn 15:23-30 (in Japanese)

Taylor ARA (1957a) Studies of the development of Zostera marina L. I. The embryo and seed. Can J Bot 35:477-499

Taylor ARA (1957b) Studies of the development of Zostera marina L. II. Germination and seedling development. Can J Bot 35:681-695

Terrados J (1993) Sexual reproduction and seed banks of Cymodocea nodosa (Ucria) Ascherson meadows on the southeast Mediterranean coast of Spain. Aquat Bot 46: 293-299

Thomas TH (1992) Some reflections on the relationship between endogenous hormones and light-mediated seed dormancy. Plant Growth ReguI 11:239-248

Turner $T$ (1983) Facilitation as a successional mechanism in a rocky intertidal community. Am Nat 121(5):729-738

Turner $T$ (1985) Stability of rocky intertidal surfgrass beds: persistence, preemption, and recovery. Ecology 66: 83-92

Tutin TG (1938) The autecology of Zostera marina in relation to its wasting disease. New Phytol 37:50-71

Ungar IA (1995) Seed germination and seed-bank ecology in halophytes. In: Kigel J, Galili G (eds) Seed development and germination. Marcel Dekker, Inc, New York, p 599-628

van Lent F, Verschuure JM (1995) Comparative study on populations of Zostera marina L. (eelgrass): experimental germination and growth. J Exp Mar Biol Ecol 185:77-91

van Vierssen W (1982) Some notes on the germination of seeds of Najas marina L. Aquat Bot 12:201-203

Walker DI, Lukatelich RJ, Bastyan G, McComb AJ (1989) Effect of boat moorings on seagrass beds near Perth, Western Australia. Aquat Bot 36:69-77

Williams SL, Davis CA [1996) Population genetic analyses of transplanted eelgrass [Zostera marina) beds reveal reduced genetic diversity in Southern California. Restor Ecol 4(2): 163-180 
Woodin SA, Marinelli RL, Lindsay SM (1998) Process-specific cues for recruitment in sedentary environments: geochemical signals? J Mar Res 56:535-558

Yasuie S, Fukuda T (1980) On the catch of seed of eelgrass, Zostera marina at Kashino Bay. Okayama Suishi Jiho 54: 141-146 (in Japanese)

Editorial responsibility: Kenneth Heck Jr (Contributing Editor), Dauphin Island, Alabama, USA
Yasuie $S$, Fukuda $T$ (1981) On the growing methods of seedling of eelgrass, Zostera marina, in the artificial pond. Saibaigiken 10:1-5 (in Japanese)

Zakaria $\mathrm{MH}$, Sidik BJ, Hishamuddin O (1999) Flowering, fruiting and seedling of Halophila beccarii Aschers. (Hydrocharitaceae) from Malaysia. Aquat Bot 65:199-207

Submitted: July 22, 1999; Accepted: December 3, 1999 Proofs received from author(s): June 27, 2000 